\title{
Listening Back: Music, Cultural Heritage and Law
}

\author{
Robbie Sykes $^{1}$ (D)
}

\begin{abstract}
As a performative activity, music has the potential to help explain the interpretive and rhetorical work of lawyering. As an aesthetic creation that reflects and shapes individual identities and social bonds, music is a cultural force that may contest or enhance political and legal power. The papers in this special issue contribute to the expanding field that pairs law and music by examining how music has affected legal practices and legal thinking in particular historical and cultural instances.
\end{abstract}

Keywords Music · Aesthetics · Culture · Identity

The voices of law and music scholarship are growing louder. This increase in volume comes after a broad neglect of sound by the legal academy. Kieran Dolin notes the "institutional hostility" music has faced [3: 30], and James Parker comments that, despite the auditory pervading life and law, "As a community of jurists, we have become deaf to law and to the problem of the acoustic." [10: 962]. These assertions can be understood in relation to the numerous explanations of legality stressing the visual experience and the authority of the image. This emphasis on the ocular resolves into a vision of society as "...an exponentially expanding videosphere, a Planet Hollywood, a YouTube universe, a gamer zone of augmented life..." [5: 2]. Traditionally, music had been greatly influential on our social structures and cultural identities. As pointed out by Bernhard Grossfeld and Jack Hiller: "History tells us that music has been seen as a means of social organization to increase and to harmonize physical and spiritual forces." [6: 1150]. This comment accounts for music's past importance. Does music continue to exert

Robbie Sykes

robbiesykes@hotmail.com

1 Law Futures Centre, Griffith University, Nathan, Australia 
such influence? While it may appear that sound has been left behind in the age of the avatar, music's dispersal through digital realms ensures that it, too, has a place of significance in the future.

For his own explorations of law's acoustic qualities, Parker has coined a term: the "soundscape of justice" [10: 964], and this expression captures some of the rich potential music holds for legal scholarship. The realm of the "soundscape" could mean many things: it may be a medium through which law speaks, or a field in which justice may be reimagined. It evokes law and music as a field of growing complexity, where legal histories, cultural struggles, and aesthetic phenomena are beginning to meet. Desmond Manderson notes that the evolution of law and music scholarship has occurred "slowly but surely" [8: 315]. In contemporary scholarship, it is a progression that has unfolded over a couple of decades.

Earlier work, such as Jack M. Balkin and Sanford Levinson's research [1], analogised classical music in concert to the rhetorical and interpretive aspects of legal advocacy and judicial decision making. In these early papers, the translation of text to performance is a leitmotif, the law brought to life by those who channel it as an orchestral score is brought to life by musicians. The pleasures and anxieties that circle around the lawyer as interpretive performer-including concerns over authenticity [2, 4]-are recurring points of interest.

Since these formative papers-works that sought inspiration in classical and, sometimes, folk music and drew parallels between playing for audiences and arguing in courtrooms - there has been a twofold enrichment of law and music scholarship. First, this enrichment involves a diversification in the types of music admitted to the interdisciplinary conversation. To list some recent examples: Lily E. Hirsh has employed rap to examine how law interprets music [7], Kieran Dolin has explored postcolonial issues in relation to Indigenous Australian culture, rethinking the nature of music and its relation to the worldviews proliferated by legal systems [3: 32-33], and Desmond Manderson has looked to punk in exploring the aesthetics and political significance of how modern art is understood. Second, there has been an enrichment of the way in which legal theoretical issues are thought through. Sara Ramshaw's work on improvisation is representative of both these developments.

Ramshaw's approach moves beyond simple analogy between legal practice and musical performance, to offer more complex analysis. Ramshaw intends for her work "...to trouble the notion of performance as immediate and singular and to question taken for granted distinctions between text and performance, writing and music, composition and improvisation." [11: 7]. More than being a simple comparative exercise, Ramshaw's work represents, as Manderson puts it, "not just a conversation on a conceptual level, but a dialogue with material implications for social and legal experience." [8: 313]. This appraisal highlights the direction in which law and music scholarship may be headed: the development of a field of enquiry that attends to how we are shaped by, and instrumental in shaping meanings through cultural transmissions of meaning. Of law and music, Manderson writes that "More must now be done to show how they matter to one another, how music can charge a social conflict with political urgency and colour it with a distinct emotional timbre." [9: 17]. The papers that comprise this special issue contribute to this goal of grounding studies of law and music in these "distinct timbres". By considering 
the specifics of different cultural legacies conveyed through music, deeper understandings of legal systems may open up, revealing new insights into courtroom practice, legal structures, and political movements.

Claudius Messner's paper on aesthetics and improvisation in jazz and law encapsulates many of the developments surveyed in this introduction. Messner brings music and law alongside each other by acknowledging that both are sustained via performance. However, Messner's nuanced approach to the interdisciplinary exchange between the two forms avoids identifying any musicality to law or legality to music, instead proposing an understanding of law that more fully recognises the aesthetic that already inheres within law itself. Messner advocates new practices of law that do not rely on the overdetermined thinking of systematic order but which learn from improvisation and seek justice by heeding context and honouring process.

Maintaining this focus on aesthetics and interpretation, Angelo Pio Buffo surveys and critiques the many points of sympathy between music and law throughout the heritage of European thought and, in doing so, explicates the demands and dilemmas of law's interpretive labours. Working on an analytic register, Pio Buffo examines the competing necessities of fidelity and responsiveness required to sustain law's vitality and sheds light on the changing nature of judicial responsibility in the modern world.

Moving from academic to political history, Tania Sebastian explains the influence of music on national identity by examining songs expressing dissent. Sebastian details the importance of protest music in the history of the Indian nation and its labour movements, highlighting a contest of influence between law and music, with both affecting not only public sentiment, but also each other, exploring music as a form of communication, a way of crystallising the lived realities of a political situation and preserving these experiences as a legacy for future generations.

Speaking to the issue of preservation, Giovanna Carugno attends to how law recognises and protects cultural heritage in its copyrighting of traditional folk music. Sebastian brings a considered approach to the topic of copyright, one of law's most direct points of contact with music, scrutinising the ways in which existing legal paradigms may be incapable of recognising and preserving the important qualities of folk music as the unique, communal expressions of a culture, and suggesting a new model that might better engage with folk, not only safeguarding, but also avoiding stifling shared traditions.

Next, music's spatial qualities and formative powers are scrutinised by Chris Waller, who argues for a greater alertness to the ambivalence of music in sites of incarceration. Waller plots the historical construction of the prisoner as subject, supplementing established understandings of music as it permeates sites of imprisonment by offering a greater focus on the complexities of carceral power dynamics. While music has often been understood as a source of refuge and agency for prisoners, it also works within power structures to impose definitions of personality and criminality upon the incarcerated.

Julia J.A. Shaw examines culture, political power, and legal reform as they converge in the constitutive and expressive powers of music. Music can exert a form 
of semiotic persuasion, the power of which lies in its indefinite meaning. Focusing on the emotional impact of music, Shaw addresses a range of genres, including classical, rap, and rock, as they have been deployed and repurposed at particular moments. With morality and ideology written into the aesthetic textures of music, music's power to galvanise polities and also to reshape thought; its powers to strengthen social bonds and delineate identities are on display here.

Robbie Sykes and Kieran Tranter also contemplate the role of music in the construction of the individual and the social order, employing the life and work of rock star David Bowie to carry out a reading of the natural law jurisprudence of John Finnis. Finnis and Bowie alike grapple with the philosophical legacy of western culture in order to bring to fruition the potential of humankind, with Bowie's iconoclasm revealing that the natural law tradition is changeable and demanding of individual responsibility.

The special issue is rounded out by another jurisprudential reading, orchestrated by Rudolf Michael Ondrich. In this paper, legal philosophy, political reality, and musical expression come together as conductor Wilhem Furtwängler's interpretation of Beethoven's Ninth's Symphony-performed during the Second World War-is read as an attempted gesture of resistance. Ondrich utilises musicology in conjunction the Carl Schmitt's theorising of sovereignty in order to explore the ramifications of Furtwängler's performance and the possibilities of protecting cultural heritage from hostile political power.

\section{References}

1. Balkin, Jack M., and Sanford Levinson. 1998-1999. Interpreting Law and Music: Performance Notes on "The Banjo Serenader" and "The Lying Crowd of Jews". Cardozo Law Review 20(5-6): 1513-1572.

2. Caudill, David S. 1998-1999. Fabricating Authenticity: Law Students as Country Music Stars. Cardozo Law Review 20(5-6): 1573-1588.

3. Dolin, Kieran. 2016. From Orpheus to Yothu Yindi: Music and Legal Cultures. Law, Culture and the Humanities 12(1): 29-38.

4. Gearey, Adam. 1998-1999. Outlaw Blues: Law in the Songs of Bob Dylan. Cardozo Law Review 20(5-6): 1401-1422.

5. Goodrich, Peter. 2014. Legal Emblems and the Art of Law: Obiter Depicta as the Vision of Governance. Cambridge: Cambridge University Press.

6. Grossfeld, Berhard, and Jack A. Hiller. 2008. Music and Law. The International Lawyer 42(3): 1147-1180.

7. Hirsh, Lily E. 2014. Rap as Threat? The Violent Translation of Music in American Law. Law, Culture and the Humanities. https://doi.org/10.1177/1743872114556858

8. Manderson, Desmond. 2014. Towards Law and Music: Sara Ramshaw, Justice as Improvisation: The Law of the Extempore. Law and Critique 25(3): 311-317.

9. Manderson, Desmond. 2016. Making a Point and Making a Noise: A Punk Prayer. Law, Culture and the Humanities 12(1): 17-28.

10. Parker, James. 2011. The Soundscape of Justice. Griffith Law Review 20(4): 962-993.

11. Ramshaw, Sara. 2016. The Paradox of Performative Immediacy: Law, Music, Improvisation. Law, Culture and the Humanities 12(1): 6-16. 